\title{
EFECTOS DEL CRÉDITO FINANCIERO EN EL SECTOR REAL DE LA ECONOMÍA ${ }^{1}$
}

\author{
Effects of financial credit on the real economy
}

\section{Daniel Alberto Pulido Ruiz² Jeffry Hansel Hernández Torres}

\section{RESUMIEN}

En este trabajo se analiza la incidencia del crédito financiero en el sector real de la economía, mediante un modelo macroeconómico Stock-Flujo Consistente desde una perspectiva teórica PostKeynesiana. Los modelos implementados analizan el resultado de la presencia de dinero a través de préstamos otorgados por el sistema financiero y su influencia en el nivel de actividad económica, dejando ver que la demanda de crédito provoca mayor consumo de los hogares.

Por otro lado, el trabajo hace notar que el crédito financiero juega un rol esencial en el estímulo de variables macroeconómicas como la producción, el consumo y el empleo, evidenciando que la demanda agregada es la que determina la oferta agregada, tanto en el corto como en el lago plazo, puesto que determina el nivel de producción y empleo. Con respecto a políticas económicas, el documento menciona el Gasto público y el aumento salarial como dos herramientas que se pueden usar para estimular el crecimiento de una economía, y que permiten favorecer los efectos positivos del sector financiero.

Por último, el sector financiero es determinante en el crecimiento de una economía, y es necesario profundizar en el uso de herramientas como las que aporta la teoría Post-Keynesiana, para monitorear, analizar y tomar decisiones adecuadas para su buen desempeño en la economía. Palabras Claves: Modelo Stock Flujo Consistente, Economía Poskeynesiana, Simulación Clasificación JEL: E12, E17, E47

\footnotetext{
${ }^{1}$ Este documento fue realizado a partir del Trabajo de Grado para optar al titulo de Economista de la Universidad de Cartagena. Asesor del Trabajo de Grado: Andrés Escobar.

${ }^{2}$ Programa de Economía de la Facultad de Ciencias Económicas- Universidad de Cartagena.
} 


\section{REFERENCIAS BIBLIOGRAFICAS}

Accoce, J., \& Mouakil, T. (2005). The monetary circuit approach: a stock-flow consistent model. En E. Hein, \& A. Truger, Money, distribution and economic policy: alternatives to orthodox macroeconomics (págs. 66-93). Cheltenham: Edward Elgar Publishing.

Alvarado Bernal, F. (2011). La hipótesis postkeynesiana del dinero endógeno: evidencia empírica para Colombia 1982-2009. Ensayos de economia (unal), 21(38): 45-83.

Arestis, P. (1996). Post-Keynesian economics: towards coherence. Cambridge Journal of Economics, 20(1): 111-135.

Arrow, K., \& Hahn, F. (1971). General competitive equilibrium. San Francisco: Holdan-day inc.

Banco Mundial. (15 de Octubre de 2015). Obtenido de Indicadores del BM: http://datos.bancomundial.org/indicador/FS.AST.DOMS.GD.ZS $\quad$ y http://datos.bancomundial.org/indicador/NY.GDP.MKTP.CD

Bezemer, D. J. (2012). Modelos contables y comprensión de la crisis financiera. Revista de Economía institucional, (14)26: 47-76.

Boyer, R. (1990). The Regulation School. New York: Columbia University Press.

Cabrera, W., Gutiérrez, J., Mendoza, J., \& Melo, V. (2010). Relación entre el riesgo sistémico del sector real y el sistema financiero. Reporte de estabilidad financiera.

Caiani, A., Godin, A., \& Lucarelli, S. (2012). Innovation and Finance: An SFC Analysis of Great Surges of Development (WP No. 733). New York: Levy Economics Institute.

Canaviri-Sillerico, G., Aliaga-Lordemann, F. (2016). Construcción de un indicador de pobreza multidimensional mediante análisis combinatorio. Panorama Económico, 24, 71-84. DOI: https://doi.org/10.32997/2463-0470-vol.24-num.0-2016-1551 
Caverzasi, E., \& Godin, A. (2013). Stock-flow Consistent Modeling through the Ages (WP No. 745). New York: Levy Economics Institute of Bard College.

Caverzasi, E., \& Godin, A. (2014). Financialization and the sub-prime crisis: a Stock-Flow Consistent model. European Journal of Economics and Economic Policies: Intervention, 12(1): 73-92.

Caverzasi, E., \& Godin, A. (2015). Post-Keynesian stock-flow consistent modelling: a survey. Cambridge Journal of Economics, 39(1): 157-187.

Clavijo-Vera, S., Vera-Sandoval, A., Vera-Concha, N. (2015). Política monetaria: reglas y discreción. Panorama Económico, 23:31-38. DOI: https://doi.org/10.32997/2463-0470-vol.23-num.1-2015$\underline{1375}$

Davidson, P. (1978). Money and the real world. Londres: Macmilan.

Davidson, P. (1980). The dual-faceted nature of the keynesian revolution: money and money wages in unemployment and production flow prices. Journal of Post Keynesian Economics, 291-307.

Davidson, P. (1988). A technical definition of uncertainty and the long-run non-neutrality of money. Cambridge Journal of Economics, 12(3): 329-337.

Davidson, P. (2006). ¿Cuáles son los elementos esenciales de la teoría monetaria poskeynesiana? En P. Piegay, \& L.-P. Rochon, Teorías monetarias Poskeynesianas (págs. 27-45). Madrid: Akal.

Deleplace, G., \& Nell, E. (1996). Money in Motion. The Post-Keynesian and Circulation Approaches. New York: Macmillan.

Dos Santos, C. H. (2005). A stock-flow consistent general framework for formal Minskyan analyses of closed economies. Journal of Post Keynesian Economics, 27(4): 711-736. 
Dos Santos, C. H., \& Macedo, e. S. (2010). Revisiting "New Cambridge”: the three financial balances in a general stock-flow consistent applied modeling strategy (Working paper $n^{\circ}$ 594). New York: Levy Economics Institute.

Dos Santos, C. H., \& Zezza, G. (2004). A Post-Keynesian stock-flow consistent macroeconomic growth model: preliminary results, WP No. 402). New York: Levy Economics Institute.

Dos Santos, C. H., \& Zezza, G. (2008). A simplified, "Benchmark", stock-flow consistent PostKeynesian growth model. Metroeconomica, (59)3: 441-478.

Eichner, A. S., \& Kregel, J. (1975). An essay on post-Keynesian theory: a new paradigm in economics. Journal of Economic Literature, 13(4); 1293-1314.

Escobar-Espinoza, A. (2016). Stock-Flow consistent models for developing countries: the case of Colombia. 19th Annual Conference on Global Economic Analysis. Recuperado de: https://www.gtap.agecon.purdue.edu/resources/download/8168.pdf

Escobar-Espinoza, A., Guevara-Castañeda, D., Uribe-Veloza, M. (2017). Modelos Computacionales y Análisis de la Política Económica en Colombia. Panorama Económico, 25, 4: 535-558. DOI: https://doi.org/10.32997/2463-0470-vol.25-num.4-2017-2088

Flores-Tapia, C., Flores-Cevallos, K. (2017). Impactos económicos inducidos por la demanda final en sectores estratégicos para el cambio de la estructura productiva del Ecuador. Panorama Económico, 25, 3: 443-458. DOI: https://doi.org/10.32997/2463-0470-vol.25-num.3-2017-2085

Fontana, G., \& Gerrard, B. (2004). A Post Keynesian theory of decision making under uncertainty. Journal of economic psychology, 619-637.

Gamero, K., Medina, E., Escobar, A. (2016). El enfoque post-keynesiano a la microeconomía: una visión alternativa. Aglala, 7, 1: 185-208. DOI: https://doi.org/10.22519/22157360.904 
Glied, S., Remler, D. K., \& Zivin, J. G. (2002). Inside the sausage factory: Improving estimates of the effects of health insurance expansion. The Milbank Quarterly, 80(4): 603-635.

Godley, W. (1996). Money, finance and national income determination: am integrated approach. Jerome Levy Institute of Bard College, WP, $\mathrm{n}^{\circ} 167$.

Godley, W. (1999). Money and credit in a keynesian model of income determination. Cambridge Journal of Economics, 23(2): 393-411.

Godley, W., \& Lavoie, M. (2007). Fiscal policy in a stock-flow consistent (SFC) model. Journal of Post Keynesian Economics, (30)1: 79-100.

Godley, W., \& Lavoie, M. (2007). Monetary economics: an integrated approach to credit, money, income, production and wealth. Hampshire \& New York: Palgrave Macmillan.

Gómez-González, J., \& Orozco, H. (2010). Un modelo de alerta temprana para el sistema financiero colombiano. Revista Ensayos Sobre Política Económica.

Graziani, A. (1989). The Theory of the Monetary Circuit. Thames Papers in Political Economy, 7: 736.

Graziani, A. (2003). The monetary theory of production. Cambridge: Cambridge University Press.

Gutiérrez, J., \& Murcia, A. (2015). El papel de la estructura del sistema financiero en la transmisión de la política monetaria. Revista Ensayos Sobre Política Económica, 33(76): 44-52.

Halevi, J., \& Taouil, R. (1998). On a post-Keynesian stream from France and Italy. The circuit approach. University of Sydney, Department of Economics, WP in Economics, $\mathrm{n}^{\circ}$ 98-08. 
Hein, E., \& Van Treeck, T. (2010). Financialisation in Post-Keynesian models of distribution and growth: a systematic review. En M. Setterfield, Handbook of Alternative Theories of Economic Growth (págs. 277-292). Cheltenham: Edward Elgar Publishing.

Heiner, R. (1983). The origin of predictable behavior. American Economic Review, 73(4), 560-595.

Heinsohn, G., \& Steiger, O. (2000). The property theory of interest and money. Londres: Routledge.

Hernandez, J., Pulido, D., Escobar, A. (2016). Efectos del crédito financiero en el sector real de la economía. Universidad de Cartagena. Recuperado de: http://hdl.handle.net/11227/3703

Howells, P. (2012). Economía Postkeynesiana. Revista Economica ICE, N865: 7-22.

Jahan, S., Mahmud, A. S., \& Papageorgiou, C. (2014). ¿Qué es la economía keynesiana?, El principio central de esta escuela de pensamiento es que la intervención del Estado puede estabilizar la economía. Finanzas y Desarrollo, 51(3): 53-54.

Kalecki, M. (1971). Selected essays on the dynamics of the capitalist economy. Cambridge: Cambridge University Press.

Keynes, J. M. (1930). The Treatise on Money. Londres: Palgrave Macmillan.

Keynes, J. M. (1936). Teoría general de la ocupación, interés y el dinero. Madrid: Ediciones Aosta.

Keynes, J. M. (1936). The general theory of employment, interest and money. Londres: Macmillan Cambridge.

Lavoie, M. (1992). Towards a new research programme for post-Keynesianism and neo-Ricardianism. Review of Political Economy, 4(1): 37-78. 
Lavoie, M. (2000). Un análisis comparativo de la teoría poskeynesiana del empleo. Investigación Económica, 15-65.

Lavoie, M. (2006). Introduction to Post-Keynesian Economic. Londres: Palgrave Macmillan.

Lavoie, M. (2007). Financialisation issues in a Post-Keynesian Stock-Flow consistent model. European Journal of Economics and Economic Policies: Intervention, 5(2): 331-356.

Lavoie, M. (2008). Towards a Post-Keynesian consensus in macroeconomics: Reconciling the Cambridge and Wall Street views. Conference of the Research Network Macroeconomics and Macroeconomic Policy. Berlin.

Lavoie, M. (2014). Post-Keynesian economics: new foundations. Massachusetts: Edward Elgar Publishing Ltd.

Lavoie, M., \& Godley, W. (2002). Kaleckian models of growth in acohernet stock-flow monetary framework: a Kaldorian view. Journal of Post Keynesian economics, 24(2): 277-311.

Le Bourva, J. (1962). Création de la monnaie et multiplicateur du crédit. Revue économique, 23: 243282.

Le Bourva, J. (1992, p. 449). Money creation and money multipliers. Review of Political Economy, 4(4): 447-462.

Le Heron, E. (2008). Fiscal and monetary policies in a Keynesian stock-flow consistent model. En J. \&. Creel. En J. Creel, \& M. Sawyer, Current Thinking on Fiscal Policy (págs. 145-175). Londres: Palgrave Macmillan.

Le Heron, E., \& Mouakil, T. (2008). A Post-Keynesian stock-flow consistent model for dynamic analysis of monetary policy shock on banking behaviour. Metroeconomica, (59)3: 405-440. 
Missaglia, M. (2015). ¿Se pueden aplicar las ideas Keynesianas Al largo plazo? unas reflexiones teóricas $y$ un modelo ilustrativo. Panorama Económico, 23: 17-30 DOI: https://doi.org/10.32997/2463-0470-vol.23-num.1-2015-1380

Moore, B. (1988). Horizontalists and Verticalists: the macroeconomics of credit money. Cambridge: Cambridge University Press.

Moore, B. J. (1989). The endogeneity of credit money. Review of political Economy, 1(1): 65-93.

Palley, T. (1996). Post Keynesian economics: debt, distribution and the macro economy. Londres: Palgrave Macmillan.

Panico, C. (1988). Interest and profit in the theories of value and distribution. Lodres: Palgrave Macmillan.

Parguez, A. (2001). Money without scarcity: from the horizontalist revolution to the theory of the monetary circuit. Cheltenham: Edward Elgar Publishing.

Pasinetti, L. (2005). The Cambridge School of Keynesian economics. Cambridge Journal of Economics, 29(6): 837-848.

Passarella, M. (2012). A simplified stock-flow consistent dynamic model of the systemic financial fragility in the New Capitalism. Journal of Economic Behavior \& Organization, 83(3): 570-582.

Pollin, R. (1991). Two theories of Money supply process: Theory and evidence. Journal of Post Keynesian, 13(3): 366-395.

Rochon, L., \& Rossi, S. (. (2003). Modern theories of money: the nature and role of money in capitalist economies. Cheltenham: Edward Elgar Publishing. 
Rochon, L.-P. (1999). The creation and circulation of endogenous money: A circuit dynamique approach. Journal of economic issues, 1-21.

Rochon, L.-P., \& Rossi, S. (2013). Endogenous money: the evolutionary versus revolutionary views. Review of Keynesian Economics, 210-229.

Rochon, L.-P., \& Setterfield, M. (2011). Postkeynesian interest rate rules and macroeconomic performance: a comparative evaluation. En C. Gnos, \& L.-P. Rochon, Credit, money and macroeconomic policy: a Post-Keynesian approach (págs. 116-141). Cheltenham: Edward Elgar publishing.

Ros, J. (2012). La Teoría General de Keynes y la macroeconomía moderna. Scielo, 71(279), pp 19-37.

Salazar-Mosquera, G. (2017). Factores determinantes del desempeño financiero en el sector manufacturero en la República del Ecuador. Panorama Económico, 25, 2: 243-254. DOI: https://doi.org/10.32997/2463-0470-vol.25-num.2-2017-2076

Sawyer, M. (2001). Kalecki on money and finance. The European Journal of the History of Economic Thought, 487-508.

Schmitt, B., \& Greppi, S. (1996). Money in motion. The Post-Keynesian and circulation approaches. En G. Deleplace, \& E. Nell, The national economy studied as a whole (págs. pp. 341-364). New York: Macmillan.

Setterfield, M. (2003). What is analytical political economy? International Journal of Political Economy, 33(2): 4-16.

Setterfield, M. (2005). La economía del crecimiento dirigido por la demanda. Madrid: Akal.

Shapiro, N. (1977). The revolutionary character of post-Keynesian economics. Journal of Economic Issues, 11(3): 541-560. 
Toporowski, J., \& Michell, J. (2012). The Stock-Flow consistent approach with active financial markets. En D. Papadimitriou, \& G. Zezza, Contributions to stock flow modelling: essays in honor of wynne godley (págs. 173-196). Londres: Palgrave Macmillan.

Van Treeck, T. (2009). A synthetic, stock-flow consistent macroeconomic model of 'financialisation'. Cambridge Journal of Economics, 33(3): 467-493.

Wicksell, K. (1936). Interest and Prices. London: Macmillan.

Wray, L. (1990). Money and credit in capitalist economies: The endogenous money approach. Cheltenham: Edward Elgar Publishing.

Zezza, G., \& Dos Santos, C. H. (2004). "The role of monetary policy in Post-Keynesian Stock-Flow consistent macroeconomic growth models". En M. Lavoie, \& M. Seccareccia, Central banking in the modern world: Alternative perspectives (págs. 183-210). Aldershot: Edward Elgar publishing.

Zezza, G., \& Dos Santos, C. H. (2006). Distribution and growth in a Post-Keynesian Stock-Flow consistent model. En N. Salvadori, Economic growth and distribution: on the nature and causes of the wealth of nations. Edward Elgar. 